\title{
Eating \& Drinking a Substance More Than 25 Times the Optimal Dose Becomes Highly Toxic. Very Important Role of Optimal Dose of Vitamin-D3 and Clothes You Wear in the Fight Against Malignancies Including Glioblastoma and Cancers of Breast, Lung, and Pancreas as well as Loss of Control of Infection due to DNA-Instability
}

\section{Yoshiaki Omura ${ }^{1,2,3,4^{*}}$}

${ }^{1}$ Family \& Community Medicine New York Medical College, United States

${ }^{2}$ President of International Association of Bi-Digital O-Ring Test Medical Society

${ }^{3}$ President and Professor of International College of Acupuncture and Electrotherapeutics

${ }^{4}$ Former Director of Medical Research, Heart-Disease Research Foundation

\section{Abstract}

Everything we eat or drink usually has an optimal dose which includes any medicine. Using optimal dose, we can obtain maximum improvement in our body with minimum amount. If you eat or drink more than 25 times the optimal dose it often creates serious toxic side effects. Particularly in the presence of electro-magnetic-field, often early stages of cancer develop. Strong EMF source such as cell phone is in the patient's pocket, multiple organs near the cellular phone in the presence of EMF can develop early stages of multiple cancers. And, if anybody spends more than one hour in short distance with patients who has abnormally increased $8-\mathrm{OH}-\mathrm{dG}$ \& integrin $\alpha 5 \beta 1$, oncogene c-Fos AB2 or increased Human Papillomavirus Type 16, cancer can become infectious to the people who stay in close distance for more than one hour including dentist with advanced cancer treating patients. But we found the optimal dose of Vitamin $\mathrm{D}_{3}$ has the most important 10 unique beneficial effects. Among them, most important 3 beneficial effects are: 1) Safe and most effective anti-cancer effect 2) It excretes viruses, bacteria, and fungus as well as toxic metals into urine 3) Acetylcholine significantly increases, which almost immediately improves brain circulation and the condition of the rest of the body, particularly improve memory and Alzheimer's condition. However, Vitamin $\mathrm{C}$ is also required for the body. But when it exceeds a few hundred mg most important beneficial effects of optimal dose of Vitamin $\mathrm{D}_{3}$ effect will be inhibited and it will become highly harmful for the body. For some patients one cup of Vitamin C rich orange juice or lemon juice completely inhibits beneficial effects of optimal dose of Vitamin $\mathrm{D}_{3}$. Also without touching the patient's body, at visible distance testing with Bi-Digital O-Ring Test, (which received a U.S. patent for non-invasive early diagnosis and treatment of cancers or cardio-vascular problems), strong BDORT negative (-) substance is touching the body surface inhibits beneficial effects of Vitamin $\mathrm{D}_{3}$. For example, blue jeans or often black underwear or BDORT strong negative (-) white artificial teeth or brassiere or lipstick which has strong negative (-) BDORT is touching the body surface, beneficial effect of optimal dose of Vitamin-D3 will be inhibited.

\section{Publication History}

Received: December 20, 2019

Accepted: June 24, 2020

Published: June 26, 2020

\section{Keywords:}

Optimal dose, Short time development of cancer, Antiviral effects, Infectious cancer, 10 unique benefits of optimal dose of Vitamin $\mathrm{D}_{3}$, Antiviral effects of Egg-whites, Inhibition effects of Vitamin $\mathrm{D}_{3}$ by excessive Vitamin

in addition to increased solar energy activity, we found many people from different parts of the world, often developed most malignant tumors such as glioblastoma of the brain, which is the most malignant brain tumor. And, the majority of the people die within 2 years and pancreatic cancer, colon cancer, lung cancer and breast cancer. In the presence of relatively high concentration of Human Papillomavirus Type 16 commonly transmitted by Egg-yolk, while Egg-white never caries Human Papillomavirus Type 16 and Egg white seems to have anti-viral effect.

*Corresponding Author: Prof. Yoshiaki Omura, Family \& Community Medicine New York Medical College, United States; E-mail: icaet@yahoo.com

Citation: Omura Y (2020) Eating \& Drinking a Substance More Than 25 Times the Optimal Dose Becomes Highly Toxic. Very Important Role of Optimal Dose of Vitamin-D3 and Clothes You Wear in the Fight Against Malignancies Including Glioblastoma and Cancers of Breast, Lung, and Pancreas as well as Loss of Control of Infection due to DNA-Instability. Int J Clin Nutr Diet 6: 153. doi: https://doi. org/10.15344/2456-8171/2020/153

Copyright: (c) 2020 Omura. This is an open-access article distributed under the terms of the Creative Commons Attribution License, which permits unrestricted use, distribution, and reproduction in any medium, provided the original author and source are credited. 
Citation: Omura Y (2020) Eating \& Drinking a Substance More Than 25 Times the Optimal Dose Becomes Highly Toxic. Very Important Role of Optimal Dose of Vitamin-D3 and Clothes You Wear in the Fight Against Malignancies Including Glioblastoma and Cancers of Breast, Lung, and Pancreas as well as Loss of Control of Infection due to DNA-Instability. Int J Clin Nutr Diet 6: 153. doi: https://doi.org/10.15344/2456-8171/2020/153

Page 2 of 3

\section{Methods \& Materials}

We found US Patented Bi-Digital O-Ring Test which was given for the detection of beneficial effect and harmful effect of any method of treatment including detection of specific molecule including identical cancer tissue the Bi-Digital O-Ring Test was given as a method of non-invasive highly sensitive electro-magnetic field resonance phenomenon between 2 identical molecules with the same amount and the method can be found from the following U.S. Patent: U.S. Patent No. 5, 188, 107, Bi-Digital O-Ring Test for Imaging and Diagnosis of Internal Organs of A Patient, February 23, 1993.

\section{Results}

Although there are many topics to cover in this article, I would like to concentrate on the clinically very important concept of optimal dose. Definition of optimal dose is the smallest amounts that induce maximum beneficial effects that can be confirmed by U.S. patented Bi-Digital O-Ring Test. Since everything we eat or drink has optimal dose but question is how to estimate optimal dose. In the past to determine optimal dose of children or adult various attempts were made and most widely used method is amount that is proportion to body weight. Unfortunately, we found children's optima dose of medication is much less than adult dose but when we compared with adult dose and accurately evaluated Bi-Digital O-Ring Test, we found optimal dose determined by Bi-Digital O-Ring Test is more than 2 times that of adult dose., while optimal dose evaluated by standard body weight proportional method is less than half of adult dose. Using BDORT, many lives of patients can be saved. Optimal dose exists for every medication. We found most reliable method is amount determined by Bi-Digital O-Ring Test, that is more than 2 times estimated by body weight proportional method which is not only too small and ineffective and some lose life. This principle can be accurately determined by optimal dose of insulin injection. Instead of injecting dosage of insulin kept on paper, we often find that amount of insulin prescribed by Doctor is often overdosed and toxic. For example, optimal dose of banana is 2- $2.5 \mathrm{~mm}$ cross section of banana but if more than 25 times of optimal dose is eaten, banana can be highly toxic, because nobody examines optimal dose of banana. Instead of optimal dose, we often eat entire banana which is more than 50 times of optimal dose which is highly toxic and contributes to development of DNA instability. In the presence of DNA instability 8-OH-dG which is proportional to DNA mutation will be increased significantly even before cancer cells are created in the presence of strong electromagnetic field. There are many highly beneficial fruits whose red outside is often BDORT negative (-) but inside has BDORT strong positive (+). An example is Dragon fruit with a white interior made with many minute black seeds. The optimal dose is a very small amount about less than the tip of $5^{\text {th }}$ finger. However, it is often eaten half or whole and persons end up eating more than 50 times of its optimal dose. As a consequence, toxic side effects were experienced and never known it's highly beneficial anti-cancer effects particularly when optimal dose of Dragon fruit is taken after optimal dose of Vitamin $\mathrm{D}_{3}$. This was not known until this author examined optimal dose in November 2018. The combination of optimal dose of Vitamin $\mathrm{D}_{3}$ and this highly beneficial fruit can be a very powerful anti-cancer treatment and stop cancer activity by proper combination of new thymus gland stimulation at the back of each hand. There are many examples of such cases which will be presented during the meeting with detailed information.

\section{Competing Interests}

The author declare that there is no competing interests regarding the publication of this article.

\section{Refereces}

1. Matthews DR, Hosker JP, Rudenski AS, Naylor BA, Treacher DF, et al (1985) Homeostasis model assessment: insulin resistance and beta-cell function from fasting plasma glucose and insulin concentrations in man. Diabetologia 28: 412-419.

2. Matsushita T, Elliger S, Elliger C, Podsakoff G, Villarreal L, et al. (1998) Adeno-associated virus vectors can be efficiently produced without helper virus. Gene Ther 5: 938-945.

3. Omura Y (1993) Bi-Digital O-Ring Test For Imaging and Diagnosis of Internal Organs of A Patient. US Patent.

4. Hemann MT, Strong MA, Hao LY, Greider CW (2001) The shortest telomere not average telomere length, is critical for cell viability and chromosome stability. Cell 107: 67-77

5. Gao GP, Alvira MR, Wang L Calcedo $R$, Johnston J, et al (2002) Nove adeno-associated viruses from rhesus monkeys as vectors for human gene therapy. Proc Natl Acad Sci USA 99: 11854-11859.

6. Gonzalez-Suarez E, Flores JM, Blasco MA (2002) Cooperation between p53 mutation and high telomerase transgenic expression in spontaneous cancer development. Mol Cell Biol 22: 7291-7301.

7. Hikosaka O, Nakamura K, Sakai K, Nakahara H (2002) Central mechanisms of motor skill learning. Curr Opin Neurobiol 12: 217-222.

8. Flores I, Cayuela ML, Blasco MA (2005) Effects of telomerase and telomere length on epidermal stem cell behavior. Science 309: 1253-1256.

9. Guarente L (2006) Sirtuins as potential targets for metabolic syndrome. Nature 444: 868-874.

10. Mas A, Montane J, Anguela XM, Munoz S, Douar AM, et al. (2006) Reversa of type 1 diabetes by engineering a glucose sensor in skeletal muscle. Diabetes 55: 1546-1553.

11. Collado M, Blasco MA, Serrano M (2007) Cellular senescence in cancer and aging. Cell 130: 223-233.

12. Buning $H$, Perabo $L$, Coutelle $O$, Quadt-Humme $S$, Hallek $M$, et al. (2008) Recent developments in adeno-associated virus vector technology. J Gene Med 10: 717-733.

13. Ornish D, Lin J, Daubenmier J, Weidner G, Epel E, et al. (2008) Increased telomerase activity and comprehensive lifestyle changes: a pilot study. Lancet Oncol 9: 1048-1057.

14. Schoeftner S, Blanco R, de Silanes IL, Munoz P, Gomez-Lopez G, et al. (2009) Telomere shortening relaxes $X$ chromosome inactivation and forces global transcriptome alterations. Proc Natl Acad Sci USA 106: 19393-19398.

15. Tafuro S, Ayuso E, Zacchigna S, Zentilin L, Moimas S, et al. (2009) Inducible adeno-associated virus vectors promote functional angiogenesis in adult organisms via regulated vascular endothelial growth factor expression. Cardiovasc Res 83: 663-671.

16. Kuhlow D, Florian S, von Figura G, Weimer S, Schulz N, et al. (2010) Telomerase deficiency impairs glucose metabolism and insulin secretion. Aging 2: 650- 658 .

17. Harley CB, Liu W, Blasco M, Vera E, Andrews WH, et al. (2011) A natura product telomerase activator as part of a health maintenance program. Rejuvenation Res 14: 45-56.

18. Jaskelioff $\mathrm{M}$, Muller FL, Paik JH, Thomas E, Jiang S, et al. (2011) Telomerase reactivation reverses tissue degeneration in aged telomerase-deficient mice. Nature 469: 102-106.

19. Sahin E, Colla S, Liesa M, Moslehi J, Muller FL, et al. (2011) Telomere dysfunction induces metabolic and mitochondrial compromise. Nature 470: 359-365.

20. Bruno B, Elsa V, Kerstin S, Agueda MT, Eduard A, et al. (2012) Telomerase gene therapy in adult and old mice delays aging and increases longevity without increasing cancer. EMBO Mol Med 4: 691-704. 
Citation: Omura Y (2020) Eating \& Drinking a Substance More Than 25 Times the Optimal Dose Becomes Highly Toxic. Very Important Role of Optimal Dose of Vitamin-D3 and Clothes You Wear in the Fight Against Malignancies Including Glioblastoma and Cancers of Breast, Lung, and Pancreas as well as Loss of Control of Infection due to DNA-Instability. Int J Clin Nutr Diet 6: 153. doi: https://doi.org/10.15344/2456-8171/2020/153

Page 3 of 3

21. Omura Y (2016) Using new non-invasive quick method to detect Borrelia Burgdorferi (B.B.) infection from specific parts of the heart in "seemingly normal" ECGs, and from the ECGs of Atrial Fibrillation (AF), a majority of AF ECGs are found to have: 1) Significant B.B. infection, 2) Markedly increased ANP, 3) Increased Cardiac Troponin I \& 4) Markedly reduced Taurine. These 4 factors were mainly localized at infected areas of the SA node area, R-\&LAtria \& pulmonary veins at the L-atrium. Acupunct Electrother Res 40: 297333.

22. Omura Y (2019) Often Lyme Disease Infection of SA-node Area \& Atrium is the cause of unrecognized Atrial Fibrillation \& proper Treatment requires at least optimal Doses of Vitamin D3 \& Amoxicillin 4 times/day. International Conference on Cardiovascular Diseases and Therapeutics in Berlin, Germany. 